\title{
Clastogenic Effect of Carthamus lanatus L. (Asteraceae)
}

Margarita Topashka-Ancheva ${ }^{a}$, Rilka Taskova $^{\mathrm{b}}$, Nedjalka Handjieva $^{\mathrm{c}^{*}}$, Bozhanka Mikhova $^{\mathrm{c}}$, and Helmut Duddeck ${ }^{\mathrm{d}}$

a Institute of Zoology, Bulgarian Academy of Sciences, 1000 Sofia, Bulgaria

b Institute of Botany, Bulgarian Academy of Sciences, 1113 Sofia, Bulgaria

c Institute of Organic Chemistry with Centre of Phytochemistry, Bulgarian Academy of

Sciences, 1113 Sofia, Bulgaria. Fax ++3592-8700-225. E-mail: nechy@orgchm.bas.bg

d Institute of Organic Chemistry, University of Hannover, 30167 Hannover, Germany

* Author for correspondence and reprint requests

Z. Naturforsch. 58c, 833-836 (2003); received April 22/May 26, 2003

The clastogenic effect of total dichloromethane, methanol and water extracts, four bioactive fractions and three individual constituents from Carthamus lanatus aerial parts were evaluated in mice by bone marrow chromosome aberration assay with mitomycin $\mathrm{C}$ as positive control. Significant differences in the percentage of aberrant mitosis of the extracts were observed. The dichloromethane extract exhibited a considerable clastogenic effect and the water extract a negligible one. Different types of chromosome aberrations and time-dependant effects for the active fractions and individual compounds were found.

Key words: Carthamus lanatus, Clastogenic Effect

\section{Introduction}

Carthamus lanatus L. (Asteraceae) is known as a plant of phytopharmaceutical importance with sedative, anti-tumor and interferon-inducing activities (Benedi et al., 1986; Yasuhuko et al., 1979). Recently, a variety of biological activities of $C$. lanatus, including antioxidant, antibacterial, antifungal activity and cytotoxicity were shown (Taskova et al., 2002, 2003; Mitova et al., 2003). Until now, the clastogenic effect of the species has not been studied. Some data about the closely related C. tinctorius were reported. Ames test and Salmonella microsome reversion assay (Morimoto et al., 1982) showed a mutagenic effect of the water extract of $C$. tinctorius flowers, which was confirmed by Esmaili-rad et al. (1995). Yin et al. (1991) demonstrated that the water extract was negative in the Ames test but positive in the chromosomal aberration and micronucleus assay in mice. The results of Nobakht et al. (2000) indicated harmful effects on cellular growth and differentiation during the embryonic development.

In the present paper, the clastogenic effect of three total extracts of $C$. lanatus, as well as their bioactive fractions and main individual constituents, was evaluated in mice using a bone marrow chromosome aberration assay.

\section{Experimental}

Plant material

Aerial parts of Carthamus lanatus L. (Asteraceae) were collected in July at the Losen village region, Sofia. A voucher specimen (No 156639) is deposited in the Herbarium of the Institute of Botany, Bulgarian Academy of Sciences (SOM). The plant was collected and identified by Dr. Rilka Taskova.

\section{Extraction and isolation of fractions and constituents}

\section{Dichloromethane extract}

Dry and ground aerial parts of $C$. lanatus $(1.5 \mathrm{~kg})$ were extracted with dichloromethane (15 1). The dry residue of the extract (29 g) was partitioned between upper (13 g) and lower (13 g) layer of hexane/methanol/water (19:19:2, v/v/v). $5 \mathrm{~g}$ of the lower layer were separated on silica gel (Merck) column with hexane and hexane/ethylacetate (20:1 to 1:10). Crude fractions 53-57 (31 mg; sterol mixture), fractions 62-64 (90 mg; fraction $\mathrm{B} ; \mathrm{R}_{\mathrm{f}}$ of oleanolic acid on TLC) and fractions 77-91 (2.7 g; $\alpha$-bisabolol fucopyranoside) were separated and further purified by SEP-Pak $\mathrm{C}_{18}$ cartridges for rapid sample preparation (Waters, Milford, USA) with methanol. 


\section{$\mathrm{MeOH}$ extract}

Dry ground aerial parts $(1.5 \mathrm{~kg})$ were extracted with methanol. The dry residue of the extract $(160 \mathrm{~g})$ was successively extracted with diethyl ether (18 g), ethyl acetate ( $4 \mathrm{~g})$ and butanol $(9 \mathrm{~g})$; water part $(110 \mathrm{~g})$. The ethyl acetate and butanol fractions were further separated by droplet counter current chromatography and column chromatography on silica gel (Merck) to yield the flavonoid constituents. The methanol extract, the ethyl acetate fraction, its main constituent, luteolin 7-O-glucoside, and a minor bioactive constituent, rutin, were tested.

\section{Water extract}

$100 \mathrm{~g}$ dried aerial parts were extracted with hot water, concentrated (15 g) and separated on Sephadex G-25 (Pharmacia) with water. The water extract and the low-molecular water fraction $(\mathrm{M}<$ $\left.10^{3}\right)(610 \mathrm{mg})$ were subjected to the analysis.

\section{Animals}

Male and female ICR mice weighing $20 \mathrm{~g} \pm$ $1.5 \mathrm{~g}$ were obtained from the Base for Experimental Animals, BAS, Slivnitza. The animals were kept at standard conditions at $20^{\circ} \mathrm{C}$ and $12 \mathrm{~h}$ light-dark cycle, having free access to food and water. Experiments were performed in accordance with the current guidelines for the care of laboratory animals.

\section{Chromosome aberrations}

The investigation was performed according to Preston et al. (1987). The samples were administered intraperitoneally (i.p.) at a dose of $1 \mathrm{mg} / \mathrm{kg}$. Mitomycin C (Kyowa, Tokyo, Japan) (1 mg/kg) was used as a positive control. The control animals were injected with $0.2 \mathrm{ml}$ solvent solution (DMSO) or $0.9 \% \mathrm{NaCl}$.

The bone marrow chromosome aberration assay was performed on groups of animals consisted of 5 males and 5 females, which were treated with the samples, the DMSO solvent, $0.9 \% \mathrm{NaCl}$ and the positive control, respectively. The animals were injected i.p. with colchicine at a dose of $0.4 \mathrm{mg} / \mathrm{kg} 24 \mathrm{~h}$ and $48 \mathrm{~h}$ after administration of the samples, of DMSO, of mitomycin C (MMC) or $0.9 \% \mathrm{NaCl}$, respectively, and $1 \mathrm{~h}$ before isolation of the bone marrow cells. The sampling times were chosen to ensure the cell analysis in case of a considerable mitotic delay. Mice were euthanized, bone marrow cells flushed from femur and hypotonized in $0.075 \mathrm{M} \mathrm{KCl}$ at $37^{\circ} \mathrm{C}$ for $20 \mathrm{~min}$. The cells were fixed in methanol/acetic acid (3:1), dropped on cold slides and air-dried. The slides were stained with $5 \%$ Giemsa solution (Sigma, St. Louis, USA). At least 50 well-spread metaphases were analysed per experimental animal at random.

\section{Statistical analysis}

Three-way analysis of variance (ANOVA) with fixed effects, followed by two-group Student's $t$ test and post hoc pairwise comparison test of Dunnett with a control was performed using BMDP4V, BMDP3D and BMDP7D programs (Dixon et al., 1990).

\section{Results and Discussion}

Three total extracts with different polarity $\left(\mathrm{CH}_{2} \mathrm{Cl}_{2}, \mathrm{MeOH}\right.$ and $\mathrm{H}_{2} \mathrm{O}$ extracts), four bioactive fractions and three main constituents were subjected to analysis of chromosomal aberrations in mitotic chromosomes of mouse bone marrow cells at a dose of $1 \mathrm{mg} / \mathrm{kg}$. The tested fractions and constituents were chosen on the ground of proven biological activities. The sterol fraction and fraction B showed significant cytotoxicity assessed by the brine shrimp assay (Mitova et al., 2003). The ethyl acetate fraction and its main constituent, luteolin 7-O-glucoside, exhibited cytotoxic and antioxidant activities (Taskova et al., 2002, 2003). The low-molecular water fraction possessed cytotoxic activity and antimicrobial activity against Staphylococcus aureus (Taskova et al., 2002).

The obtained data were presented in protocols according to Preston et al. (1987) and summarized in Table I. The solvent, dimethyl sulfoxide (DMSO) $(0.01 \mathrm{ml} / \mathrm{g})$ caused statistically insignificant increase of the percentage of aberrant mitosis vs. the control $(0.9 \% \mathrm{NaCl})$. The positive control, mitomycin C (MMC) $(1 \mathrm{mg} / \mathrm{kg})$ caused $12.8 \pm$ $0.8 \%$ aberrations $24 \mathrm{~h}$ after administering. After $48 \mathrm{~h}$ the percentage decreased to $5.0 \pm 0.33$, which is in agreement with the time-dependent frequencies of aberrations after a single injection of $1 \mathrm{mg} / \mathrm{kg}$ MMC described by Hayashi et al. (1984). 
Table I. Frequencies of chromosome aberrations in affected mouse bone marrow cells after i. $p$. treatment of fractions and constituents of Carthamus lanatus aerial parts ${ }^{\mathrm{a}}$.

\begin{tabular}{|c|c|c|c|c|c|c|c|c|}
\hline \multirow[t]{2}{*}{ Sample ${ }^{\mathrm{b}}$} & \multirow{2}{*}{$\begin{array}{c}\text { Interval } \\
{[\mathrm{h}]}\end{array}$} & \multicolumn{4}{|c|}{ Type of aberrations } & \multirow{2}{*}{$\begin{array}{l}\text { Percentage } \\
\text { of cells with } \\
\text { aberrations } \\
X \pm \text { s.e.m. }\end{array}$} & \multirow{2}{*}{$\begin{array}{c}\text { Statistical } \\
\text { significance }^{c}\end{array}$} & \multirow{2}{*}{$\begin{array}{c}\text { Statistical } \\
\text { significance }^{\mathrm{d}}\end{array}$} \\
\hline & & Breaks & Fragments & $\mathrm{c} / \mathrm{c}$ & $t / t$ & & & \\
\hline \multirow[t]{2}{*}{ Dichloromethane extract } & 24 & 16 & 8 & 24 & 2 & $10.0 \pm 0.86$ & $* *$ & \\
\hline & 48 & 12 & 4 & 18 & 8 & $8.4 \pm 0.97$ & $* *$ & $*$ \\
\hline \multirow[t]{2}{*}{ Sterol fraction } & 24 & 11 & 9 & 6 & 0 & $6.5 \pm 0.73$ & $* *$ & ** \\
\hline & 48 & 3 & 4 & 9 & 0 & $3.2 \pm 0.53$ & $*$ & \\
\hline \multirow{2}{*}{ Fraction B } & 24 & 4 & 0 & 10 & 0 & $2.8 \pm 0.32$ & & \\
\hline & 48 & 13 & 0 & 7 & 0 & $4.0 \pm 0.61$ & $* *$ & $* *$ \\
\hline \multirow[t]{2}{*}{$\alpha$-Bisabolol fucopyranoside } & 24 & 9 & 5 & 0 & 0 & $2.6 \pm 0.42$ & & $* *$ \\
\hline & 48 & 7 & 15 & 0 & 2 & $5.6 \pm 0.40$ & & \\
\hline \multirow[t]{2}{*}{$\mathrm{MeOH}$ extract } & 24 & 6 & 8 & 16 & 2 & $6.8 \pm 0.43$ & $* *$ & ** \\
\hline & 48 & 4 & 1 & 22 & 1 & $5.6 \pm 0.39$ & $* *$ & \\
\hline \multirow[t]{2}{*}{ Ethyl acetate fraction } & 24 & 8 & 0 & 16 & 0 & $4.8 \pm 0.53$ & $* *$ & $* *$ \\
\hline & 48 & 7 & 0 & 13 & 0 & $2.6 \pm 0.42$ & & \\
\hline \multirow[t]{2}{*}{ Luteolin 7-O-glucoside } & 24 & 8 & 3 & 18 & 0 & $5.4 \pm 1.16$ & $* *$ & $* *$ \\
\hline & 48 & 14 & 6 & 13 & 0 & $6.8 \pm 1.08$ & $* *$ & \\
\hline \multirow[t]{2}{*}{ Rutin } & 24 & 0 & 0 & 0 & 0 & $0.6 \pm 0.30$ & & $* *$ \\
\hline & 48 & 5 & 0 & 15 & 0 & $4.2 \pm 0.46$ & $* *$ & \\
\hline \multirow[t]{2}{*}{ Water extract } & 24 & 4 & 0 & 11 & 1 & $3.2 \pm 0.49$ & $* *$ & $* *$ \\
\hline & 48 & 2 & 0 & 8 & 0 & $2.0 \pm 0.63$ & & $* *$ \\
\hline \multirow{2}{*}{ Low-molecular water fraction } & 24 & 5 & 0 & 7 & 0 & $2.8 \pm 0.44$ & & \\
\hline & 48 & 1 & 0 & 8 & 0 & $1.8 \pm 0.36$ & & \\
\hline \multirow[t]{2}{*}{ Solvent: DMSO } & 24 & 1 & 1 & 4 & 0 & $1.4 \pm 0.30$ & control & $* *$ \\
\hline & 48 & 2 & 0 & 2 & 0 & $0.8 \pm 0.32$ & control & $* *$ \\
\hline \multirow[t]{2}{*}{ Control: $0.9 \% \mathrm{NaCl}$} & 24 & 1 & 0 & 2 & 0 & $0.6 \pm 0.30$ & & $* *$ \\
\hline & 48 & 0 & 0 & 3 & 0 & $0.6 \pm 0.30$ & & $* *$ \\
\hline \multirow[t]{2}{*}{ Mitomycin $\mathrm{C}$} & 24 & 31 & 24 & 9 & 0 & $12.8 \pm 0.8$ & $* *$ & control \\
\hline & 48 & 10 & 13 & 0 & 0 & $5.0 \pm 0.33$ & $* *$ & control \\
\hline
\end{tabular}

a Number of methaphases scored 500 .

b Dose of $1 \mathrm{mg} / \mathrm{kg}$.

c Dunnet control group comparison test with DMSO as a control group.

d Dunnet control group comparison test with the positive control as a control group. $(* * \mathrm{p}<0.01 ; * \mathrm{p}<0.05 ; \mathrm{p}>0.05-$ not significant $)$.

Significant differences in the percentage of aberrant mitosis of the studied samples, the types of chromosome aberrations and time-dependant effects after treatment were observed. The dichloromethane extract showed the highest clastogenic effect. Relatively high percentage of aberrations was found also for the methanol extract, the sterol fraction and luteolin 7-O-glucoside. Both, the water extract and its low-molecular water fraction, produced low percentage of aberrations.

The scored chromosome aberrations were predominantly breaks and centromeric-centromeric fission (c/c) and more rarely fragments and telomeric-telomeric fission $(\mathrm{t} / \mathrm{t})$. For example, fraction B, the ethyl acetate and low molecular fractions, and rutin caused only breaks and c/c fission; the sterol fraction gave also fragments; the water extract caused breaks, $\mathrm{c} / \mathrm{c}$ and $\mathrm{t} / \mathrm{t}$ fissions.

Time-dependent frequencies of the aberrant metaphases were observed. The effect of the crude extracts and fractions (except fraction B) followed the relationship observed for MMC, lower values at $48 \mathrm{~h}$ vs. $24 \mathrm{~h}$ after dosing. Fraction $\mathrm{B}$ and the individual compounds caused increasing in the aberrant mitosis $48 \mathrm{~h}$ after administering. It could be presumed that the studied glycosides ( $\alpha$-bisabolol fucopyranoside, luteolin 7-O-glucoside and rutin) metabolize in the mouse organism to the corresponding aglycones or other metabolites with stronger clastogenic effects. For example, rutin did not damage the chromosomes after $24 \mathrm{~h}$, but after $48 \mathrm{~h}$ caused a significant increase of aberrant mito- 
sis (Table I, p < 0.01). Rutin metabolizes to quercetin, which is known to inhibit the growth of cells in various human cancers (Yoshida et al., 1990; Ranelletti et al., 1992; Scambia et al., 1991) and has selective cytotoxicity in malignant cells (Jagadeeswaran et al., 2000).

In conclusion, all tested samples showed lower percentage of aberrations $v s$. mitomycin $\mathrm{C}$ and in this sense are less harmful for mammalian cells. The water extract and the low-molecular water fraction did not show a statistically significant

Benedi J., Iglesias I., Manzanares J., and Zaragoza F. (1986), Preliminary pharmacological studies of Carthamus lanatus L. Plant. Med. Phytother. 20, 25-30.

Dixon J., Brown M., Engelman L., and Jennrich R. (1990), BMDP Statistical Software Manual. UCLA Press, Berkely.

Esmaili-rad S., Daneshvar N., Rastegar-Lati A., and Mahmoudian M. (1995), Mutagenicity screening of food coloring agents (herbal and synthetic) with Ames test. In: Proceedings of the $12^{\text {th }}$ Iranian Congress of Physiology and Pharmacology. IUMS Press, Teheran, pp. 414

Hayashi M., Sofuni T., and Ishidate M. Jr. (1984), Kinetics of micronucleus formation in relation to chromosomal aberrations in mouse bone marrow. Mutat. Res. 127, 129-137.

Jagadeeswaran R., Thirunavukkarasu C., Gunasekaran P., Ramamurty N., and Sakthisekaran D. (2000), In vitro studies on the selective cytotoxic effect of crocetin and quercetin. Fitoterapia 71, 395-399.

Mitova M., Taskova R., Popov S., Berger R., Krings U., and Handjieva N. (2003), GC/MS analysis of some bioactive constituents from Carthamus lanatus L. Z. Naturforsch. 58c, 697-703.

Morimoto I., Watanabe F., Osawa T., Okitsu T., and Kada T. (1982), Mutagenicity screening of crude drugs with Bacillus subtilis res-assay and Salmonellas microsome reversion assay. Mutat. Res. 97, 81-102.

Nobakht M., Fattahi M., Hoormand M., Milanian I., Rahbar N., and Mahmoudian M. (2000), A study on the teratogenic and cytotoxic effects of safflower extract. J. Ethnopharmacol. 73, 453-459.

Preston R., Dean B., Galloway S., Holden H., McFee A. F., and Sheldy M. (1987), Mammalian in vivo cytogenetic assay analysis of chromosome aberrations in bone marrow cells. Mutat. Res. 189, 157-165. increase in aberrations, either at $24 \mathrm{~h}$ or $48 \mathrm{~h}$, which suggests that the plant does not pose a great hazard when used as herbal medicine.

\section{Acknowledgements}

The authors are grateful to Deutsche Forschungsgemeinschaft (DFG), Germany for financial support of this research. We thank Dr. N. Neykov (National Institute of Meteorology and Hydrology, Bulgarian Academy of Sciences) for performing the statistical analysis.
Ranelletti F., Ricci R., Larocca L., Maggiano N., Capelli A., Scambia G., Benedetti-Panici P., Mancuso S., Rumi C., and Piantelli M. (1992), Growth-inhibitory effect of quercetin and presence of type-II estrogenbinding sites in human colon-cancer cell lines and primary colorectal tumors. Int. J. Cancer 50, 486492.

Scambia G., Ranelletti F., Benedetti P., Panici P., Piantelli M., Bonanno G., De Vincenzo R., Ferrandina G., Pierelli L., Capelli A., and Mancuso S. (1991), Quercetin inhibits the growth of a multidrug-resistant estrogen-receptor-negative MCF-7 human breast-cancer cell line expressing type II estrogen-binding sites. Cancer Chemoth. Pharm. 28, 255-258.

Taskova R., Mitova M., Najdenski H., Tzvetkova I., and Duddeck H. (2002), Antimicrobial activity and cytotoxicity of Carthamus lanatus. Fitoterapia 73, 540543.

Taskova R., Mitova M., Mikhova B., and Duddeck H. (2003), Bioactive phenolics from Carthamus lanatus L. Z. Naturforsch. 58c, 704-707.

Yasuhuko K., Kanagawa Y., Seishi K., and Takashi H., Wasserlöslicher Interferoninduktor, Verfahren zu seiner Gewinnung und dessen Verwendung. Ger Offen 3,004,018 Appl. 07 Feb. 1979.

Yin X. J., Liu D., Wang H. C., and Zhou Y. (1991), A study on mutagenicity of 102 raw pharmaceuticals used in Chinese traditional medicine. Mutat. Res. 260, $73-82$.

Yoshida M., Sakai T., Hosokawa N., Marui N., Matsumoto K., Fujioka A., Nishino H., and Aoike A. (1990), The effect of quercetin on cell cycle progression and growth of human gastric cancer cells. FEBS Lett. 260, 10-13. 